\title{
The Spanish version of the Skin Picking Impact Scale (SPIS) and its Short form (SPIS-S)
}

\author{
La versión en español de la Skin Picking Impact Scale (SPIS) y de su forma \\ abreviada (SPIS-S)
}

\author{
Iván Barrios $\mathbb{D}^{1,2}$, Mohammad Jafferany $\mathbb{B}^{3}$, Noelia Ruiz Díaz $\mathbb{1}^{1}$, Oscar García ${ }^{1}$, José Almirón-Santacruz $\mathbb{1}^{1}$, Marcelo

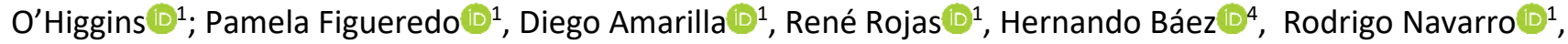 \\ João Mauricio Castaldelli-Maia $\mathbb{1}^{5,6}$, Antonio Ventriglio $\mathbb{D}^{7}$, Jorge Villalba-Arias $\mathbb{1}^{1,8}$, Julio Torales $\mathbb{1}^{1,9,10}$
}

${ }^{1}$ Universidad Nacional de Asunción, Facultad de Ciencias Médicas, Cátedra de Psiquiatría, San Lorenzo, Paraguay.

2Universidad Nacional de Asunción, Facultad de Ciencias Médicas, Cátedra de Bioestadística, Santa Rosa del Aguaray, Paraguay.

${ }^{3}$ Central Michigan University, Department of Psychiatry, Mount Pleasant, Michigan, United States of America.

${ }^{4}$ Universidad Nacional de Asunción, Facultad de Ciencias Médicas, Cátedra de Pediatría, San Lorenzo, Paraguay.

${ }^{5}$ Fundação do ABC, Department of Neuroscience, Santo André, SP, Brazil.

${ }^{6}$ University of São Paulo, Department of Psychiatry, São Paulo, SP, Brazil.

7University of Foggia, Department of Clinical and Experimental Medicine, Foggia, Italy.

8 Universidad Nacional de Asunción, Facultad de Ciencias Médicas, Cátedra de Psiquiatría, Santa Rosa del Aguaray, Paraguay.

๑Universidad Nacional de Asunción, Facultad de Ciencias Médicas, Cátedra de Psicología Médica, San Lorenzo, Paraguay.

10Universidad Nacional de Asunción, Facultad de Ciencias Médicas, Cátedra de Socioantropología, Santa Rosa del Aguaray, Paraguay.

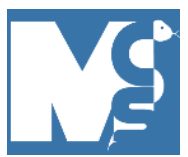

Received: $21 / 03 / 2021$

Revised: 09/04/2021

Accepted: 19/04/2021

\section{Corresponding author}

Julio Torales

Universidad Nacional de Asunción

San Lorenzo - Paraguay

jtorales@med.una.py

\section{Conflicts of interests}

The authors declare that there is no conflict of interest.

\section{Funding}

The authors received no financial support for the research, authorship, and/or publication of this article.

This article is published under Creative Commons Attribution 4.0 International License.

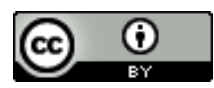

\section{ABSTRACT}

Introduction: The Skin Picking Impact Scale (SPIS) is a self-report rating scale that assess the psychosocial impact of excoriation disorder. In this study the SPIS was translated into Spanish and its reliability was measured. Similarly, its short version (SPIS-S) has been translated and tested. Methodology: The recruitment has been performed through a survey launched on social media. All subjects were older than 18 years and self-reported being diagnosed with an excoriation disorder. 281 individuals were rated for the validation analysis. SPIS has been translated into Spanish and validated through an exploratory and confirmatory factorial analysis. Participants have been also scored with the Skin Picking Scale-Revised (SPS-R). Results: On factor at the exploratory factorial analysis has a raw eigenvalue greater than 1 , with $65.5 \%$ of total variance. The confirmatory analysis confirmed that the scale is one-dimensional. Cronbach's alpha also confirmed a good internal consistency ( $\alpha=0.934$ for the SPIS and $\alpha=0.882$ for the SPIS-S). Scores between the two scales (SPIS and the SPS-R) have shown a good convergence $(r=0.592, p<0.0001)$. Conclusion: The Spanish version of SPIS and its short version show good psychometric properties and adequately reproduce the onedimensional model of the original English version.

Keywords: Excoriation disorder; Validity; Reliability; Factor analysis.

\section{RESUMEN}

Introducción: la Skin Picking Impact Scale (SPIS) es una escala autoaplicada de que evalúa el impacto psicosocial del trastorno de excoriación. En este estudio se tradujo la SPIS al español y se midió su confiabilidad. Asimismo, se tradujo y se evalúo su versión corta (SPIS-S). Metodología: el reclutamiento se realizó a través de una encuesta distribuida a través de redes sociales. Todos los sujetos participantes fueron mayores de 18 años e informaron haber sido diagnosticados con trastorno de excoriación. 281 individuos calificaron para el análisis de validación. La SPIS fue traducida al español y validada a través de análisis factorial exploratorio y análisis factorial confirmatorio. Los participantes también fueron evaluados con la versión revisada de la Skin Picking Scale - Revised (SPS-R). Resultados: en el análisis factorial exploratorio, un valor tenía un valor propio bruto mayor que 1 , con $65,5 \%$ de la varianza total. El análisis confirmatorio determinó que la escala es unidimensional. El alfa de Cronbach también confirmó una buena consistencia interna ( $\alpha=0,934$ para la SPIS y $\alpha=0,882$ para la SPIS-S). Las puntuaciones entre las dos escalas (SPIS y SPSR) mostraron una buena convergencia $(r=0,592, p<0,0001)$. Conclusión: la versión en español de la SPIS y de su versión abreviada muestran buenas propiedades psicométricas y reproducen adecuadamente el modelo unidimensional de la versión original en inglés.

Palabras clave: Trastorno de excoriación; Validez; Fiabilidad; Análisis factorial 


\section{INTRODUCTION}

Excoriation disorder (ED) is also well-known as compulsive skin-picking, pathological skin-picking, psychogenic excoriation, or dermatillomania (1-3). This condition is characterized by a recurrent picking of skin, leading to skin lesions and significant distress or functional impairment $(3,4)$. Affected patients may show typical injuries, or report bleeding and pain after picking their skin (3). Even though the patient is aware of the self-destructiveness of this behavior, he/she shows poor control about it (5), despite having made repeated attempts to decrease or interrupt it.

ED is also associated with relevant impairment in the occupational, social and personal functioning. Symptoms cannot be better explained by the presence of another mental disorder, medical condition or substance use (6). The repetitive behavior may be carried out with nails or instruments (tweezers, needles, among others) and causes tissue damage, cellulite, deforming scars, in addition to significant aesthetic and emotional distress (7).

ED was considered as an impulse control disorder (8), although, according to the fifth edition of the Diagnostic and Statistical Manual of Mental Disorders of the American Psychiatric Association (DSM 5), it is currently included in the obsessive-compulsive disorder and other related disorders section (6).

The assessment of ED is based on clinicianadministered and self-report rating scales. Selfadministered scales reported a high psychometric validity $(9,10)$. Skin Picking Scale (SPS) and Skin Picking Impact Scale (SPIS) are self-administered scales for ED, and measure its clinical severity and related psychosocial impact, respectively $(10,11)$. Nonetheless, both of them are not validated in Spanish. In this study the Skin Picking Impact Scale (SPIS) and its short version (SPIS-S) have been translated into Spanish and their reliability have been measured.

The assessment of ED is based on clinicianadministered and self-report rating scales $(9,10,12)$. Among the clinician-administered rating scales, the Yale-Brown Obsessive-Compulsive Scale modified for neurotic excoriation and the Skin Picking Treatment Scale are available (13). Skin Picking Scale (SPS) and Skin Picking Impact Scale (SPIS) are self-administered scales for ED, measuring the clinical severity of the disorder and the psychosocial impact of it, respectively $(12,14)$. Self-administered scales report a high psychometric validity (13). It is noteworthy that a correct assessment of ED patients may lead to tailored therapeutic options.

\section{METHODOLOGY}

\section{Participants}

Participants were recruited through an Internet-based survey, spread through social media, during December 2020. All participants received complete information about the aim of the study, privacy and dataprocessing. No payment has been foreseen for completing the survey. Subjects were older than 18 years and self-reported being diagnosed with an excoriation disorder, according to the criteria of the American Psychiatric Association, and accepted to participate in the study.

The sample size was calculated using the Epidat epidemiological package. Assuming an expected ED frequency of $5 \%(15)$, a confidence level of $95 \%$, and a precision of $2.6 \%$, the minimum sample was established in 270 participants. Finally, 637 subjects were surveyed. Of them, 281 subjects were selected as reporting current symptoms of ED.

Current symptoms were detected as the presence of positive answers to the following two questions: a) At present, do you perform recurrent skin picking, that causes tissue damage, bleeding, or pain? And, b) Do you experience discomfort or impairment resulting from this behavior? The Internet-based survey approach was used taking into account that there is supporting evidence that responses to online surveys may provide similar findings to those reported through "in person" samples (16).

In this research, all measures, conditions, data exclusions, and procedure for the determination of the sample size, to the best of our knowledge, have been reported.

\section{Measures}

\section{The Skin Picking Impact Scale (SPIS)}

The SPIS is a self-administered rating scale that assesses the severity of ED in terms of psychosocial impact. The scale is composed of 10 items. Each item reports a score ranging from 0 to 5 , with a total score ranging from 0 to 50 points. A score of 7 has been determined as the cut-off point from which the existence of a significant psychosocial impact is considered (10). The SPIS-S includes questions 2, 5, 6 and 7 of the original version, with the same scores as the extended version and good psychometric properties (17).

The SPIS has demonstrated good internal consistency in previous research $(\alpha=0.93)(15)$. Cronbach's alpha for the current sample is described in the results section of the present study. 


\section{The Skin Picking Scale-Revised (SPS-R)}

The SPS-R is a revised version of the Skin Picking Scale (SPS). It is self-administered and assesses the severity of ED in the 7 days prior to the evaluation. The scale is composed of 8 items. Each item gets a score ranging from 0 to 4 , with a total score ranging from 0 to 32 points. SPS-R explores two dimensions: (a) severity of symptoms (frequency and intensity of the urge to pick, time spent picking, and ability to control it); and, (b) the impairment due to skin picking (emotional distress, social avoidance, and skin damage due to skin picking) $(9,14)$. In this study, the Spanish version of the SPS-R was used, which has demonstrated good validity and internal consistency ( $\alpha=0.884 ; 0.889)$ in previous samples $(12,18)$. Cronbach's alpha for the current sample is described in the results section of the present study.

\section{Translation process and validation}

The translation process was divided in three phases: (a) the original English version ( $v 1)$ was translated into Spanish (v2); (b) a bilingual expert translated back the Spanish version (v2) into English (v3); (c) finally, a native English speaker compared, sentence by sentence, the new translation (v3) with the original English version ( $\mathrm{v} 1$ ), in order to verify if they were equivalent in meaning. Some changes or improvements were made after the comparison was made and the Spanish version was administered to 20 individuals, as a pilot test, in order to verify if the questionnaire was understandable. After the pilot test, the final Spanish version was obtained (Table 1).

\section{TABLE 1. THE SPANISH VERSION OF THE SPIS.}

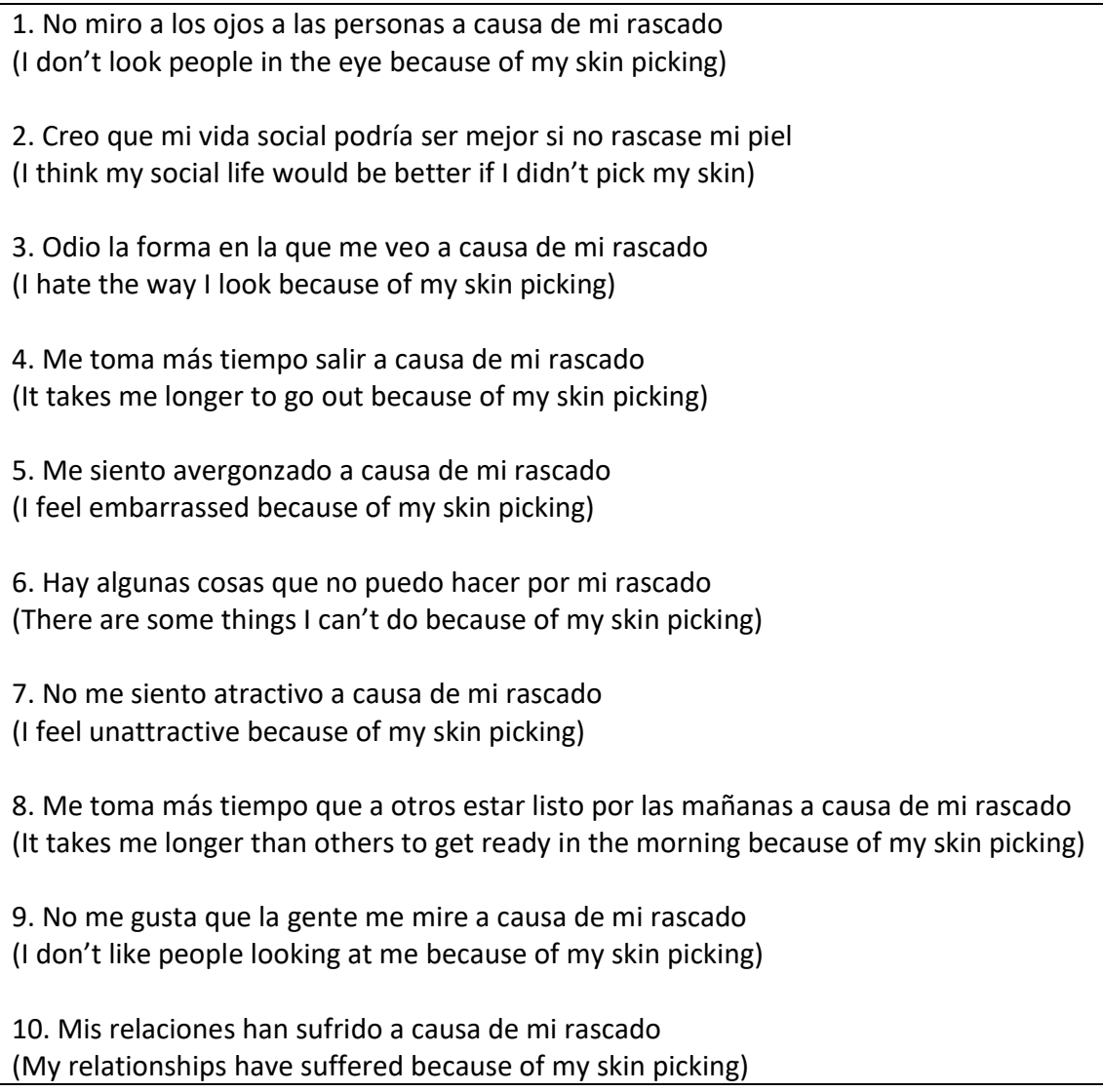

\section{Statistical analysis}

To test the construct validity, the pertinence of performing an exploratory factor analysis was preliminary assessed using the Kaiser-Meyer-Olkin (KMO; SPSS software - version 23) test for sample adequacy and the Bartlett's Test of Sphericity. The sample was randomly divided into two subsamples, in which exploratory factorial analysis was performed with the afore-mentioned software and confirmatory factorial analysis was performed with JASP statistical software (version 0.10.2.0). Exploratory factorial analysis aimed to obtain the factorial structure, to be confirmed with confirmatory analysis. Exploratory factorial analysis was made using principal axis factoring with promax rotation, with a kappa value of 4. Confirmatory analysis was made through diagonally 
weighted least squares (DWLS) estimation procedure, taking into consideration the sample size.

Chi square test was performed, and the following fit indices were used to assess the model: $\mathrm{CFI}, \mathrm{NFI}$, and RMSEA. For the validity of model, CFI and NFI values had to be at least 0.90 and RMSEA value below 0.05 (19).

Reliability was measured with Cronbach's alpha. Alpha values are described as excellent (0.93-0.94), strong (0.91-0.93), reliable (0.84-0.90), robust (0.81), fairly high (0.76-0.95), high (0.73-0.95), good (0.71-0.91), relatively high (0.70-0.77), slightly low (0.68), reasonable $(0.67-0.87)$, adequate $(0.64-0.85)$, moderate $(0.61-0.65)$, satisfactory $(0.58-0.97)$, acceptable $(0.45-0.98)$, sufficient $(0.45-0.96)$, not satisfactory (0.4-0.55), and low (0.11) (20). Convergent validity was measured between the scores of the SPIS and the SPS-R.

\section{Ethical considerations}

The study was approved by the Department of Psychiatry of the National University of Asunción, School of Medical Sciences (Paraguay). Data were treated with confidentiality, equality, and justice, respecting the Helsinki principles. Participants who required a feedback from the survey were invited to write down their email address and received information or specific helpful suggestions.

\section{RESULTS}

Kaiser-Meyer-Olkin (KMO) test was adequate $(\mathrm{KMO}=0.919)$ and sphericity tested significantly $(p<0,0001)$. These results confirmed that the sample was adequate for a factorial analysis. Secondly, the sample was randomly divided into two subsamples (subsample 1, $n=142$; subsample $2, n=139$ ), in order to perform exploratory and confirmatory factorial analysis.

\section{Factorial analysis}

Since only the first factor had a raw eigenvalue greater than the parallel random values, thus one factor was retained. Before extraction, this factor explained $65.5 \%$ of total variance. After extraction, this factor explained $62.3 \%$ of total variance. Communality values were acceptable, except for item 1 (Table 2).

\section{TABLE 2. RESULTS FROM THE EXPLORATORY FACTOR ANALYSIS WITH PROMAX ROTATION ON THE SPANISH VERSION OF THE SPIS.}

\begin{tabular}{|c|c|}
\hline Items & Communality \\
\hline $\begin{array}{l}\text { 1.No miro a los ojos a las personas a causa de mi rascado } \\
\text { (I don't look people in the eye because of my skin picking) }\end{array}$ & 0.114 \\
\hline $\begin{array}{l}\text { 2. Creo que mi vida social podría ser mejor si no rascase mi piel } \\
\text { (I think my social life would be better if I didn't pick my skin) }\end{array}$ & 0.546 \\
\hline $\begin{array}{l}\text { 3. Odio la forma en la que me veo a causa de mi rascado } \\
\text { (I hate the way I look because of my skin picking) }\end{array}$ & 0.656 \\
\hline $\begin{array}{l}\text { 4. Me toma más tiempo salir a causa de mi rascado } \\
\text { (It takes me longer to go out because of my skin picking) }\end{array}$ & 0.716 \\
\hline $\begin{array}{l}\text { 5. Me siento avergonzado a causa de mi rascado } \\
\text { (I feel embarrassed because of my skin picking) }\end{array}$ & 0.824 \\
\hline $\begin{array}{l}\text { 6. Hay algunas cosas que no puedo hacer por mi rascado } \\
\text { (There are some things I can't do because of my skin picking) }\end{array}$ & 0.715 \\
\hline $\begin{array}{l}\text { 7. No me siento atractivo a causa de mi rascado } \\
\text { (I feel unattractive because of my skin picking) }\end{array}$ & 0.754 \\
\hline $\begin{array}{l}\text { 8. Me toma más tiempo que a otros estar listo por las mañanas a causa de mi rascado } \\
\text { (It takes me longer than others to get ready in the morning because of my skin picking) }\end{array}$ & 0.712 \\
\hline $\begin{array}{l}\text { 9. No me gusta que la gente me mire a causa de mi rascado } \\
\text { (I don't like people looking at me because of my skin picking) }\end{array}$ & 0.644 \\
\hline $\begin{array}{l}\text { 10. Mis relaciones han sufrido a causa de mi rascado } \\
\text { (My relationships have suffered because of my skin picking) }\end{array}$ & 0.548 \\
\hline
\end{tabular}

The one-factor model, as found in the exploratory factorial analysis performed on subsample 1, was assessed with confirmatory factorial analysis in subsample 2 . The model adjustment was valid, according to all fit indices (S-B $\chi 2=978.119, \mathrm{df}=45$, $\mathrm{p}>0,05 ; \mathrm{RMSEA}=0 ; \mathrm{CFI}=1, \mathrm{NFI}=0.986)$. This may confirm that the model of the Spanish version of SPIS can reproduce the same one-dimensionality found in the original English version of the scale.

\section{Internal consistency and correlation between factors}

For the SPIS, Cronbach's alpha showed a valid internal consistency $(\alpha=0.934)$. It is of note that the deletion of the first item of the scale would rise Cronbach's alpha 
to $\alpha=0.941$. SPIS-S Cronbach's alpha showed a valid internal consistency too ( $\alpha=0.882)$. SPIS's mean score and standard deviation were $11.5 \pm 12.4$.

For the SPS-R, Cronbach's alpha showed a valid internal consistency too $(\alpha=0.889)$, the average score of the scale was 1.083 , with a standard deviation of 0.907 . The average correlation between items was 0.505 . Scores between the two scales (SPIS and the SPS-R) have shown a good convergence $(r=0.592, p<0.0001)$, which indicates a direct and strong relationship between both scales and a good validity of the Spanish version of the SPIS.

\section{DISCUSSION}

Three elements are invariably observed in patients with $\operatorname{ED}(3,21):$ a) Recurrent skin picking, that causes tissue damage, bleeding, or pain; b) Significant discomfort or impairment resulting from skin picking; and, c) The behavior is not due to other medical or psychiatric illnesses or substance use (e.g., body dysmorphic disorder, amphetamine use, dermatological diseases, respectively).

The self-inflicted nature of skin lesions and the lack of delusions and/or hallucinations differentiate ED from other psychiatric conditions (such as delusional infestation) or dermatological diseases (such as dermatitis artefacta), which may lead to skin damage or mutilation (3).

Skin picking is characterized by acute episodes with skin scratching, "digging" and damaging (22). The behavior may cause clinically significant injuries with preceding psychosocial stress in up to $90 \%$ of patients (22). Skin picking can be also ritualized, often at bedtime, and patients may feel unhappy and guilty for the disfigurement caused.

These negative feelings increase progressively as the skin picking continues (4). Stress, sadness, anger, anxiety, or specific situations like talking on the phone, being in bed, reading, or watching television can facilitate skin picking episodes (23).

Our results show that the Spanish version of SPIS reports acceptable psychometric properties and validity in terms of reliability and internal consistency. As in the original English version (14), in the Spanish version one well defined factor was found, with good factorial weights.

Regarding the confirmation analysis, all indices give acceptable values that confirm the model, which implies that the scale fully reproduces the original model of the authors. Internal consistency was correct and concordant with what the original authors reported. The same applies for the short version of the scale $(10,17)$.

Finally, good convergence was found between the scores of the SPIS and the SPS-R, which indicates a direct and strong relationship between both scales and a good validity of the Spanish version of the SPIS. These results are consistent with the existing literature $(15,24)$.

Limitations of this research may include the lack of data in order to determine if there were any other difference in sociodemographic factors (e.g., race, ethnicity, education level, employment, etc.) or clinical characteristics (e.g., comorbidity, urge to pick skin, etc.) that might be present between the included participants and the excluded subjects. Furthermore, the scope of this article could have been greater if additional data had been available (e.g., information on discriminant association with other obsessivecompulsive related disorders or emotional disorders). Another limitation may include the fact that we completely relied on self-report measures in order to include/exclude participants. Finally, test-retest reliability was not calculated, since contact information of recruited subjects were not collected for a second assessment.

A strength point of this research is the measurement of psychometric properties of the Spanish version of SPIS: this might suggest a valuable assessment tool for Spanish-speaking patients affected by ED. In fact, if not correctly assessed, diagnosed and successfully treated, ED may evolve into a chronic form with severe psychosocial impairment and serious medical complications. Clinicians would need an assessment instrument for ED (such as SPIS, possibly standardized according to the international guidelines). Also, therapeutic approaches should address the control of this repetitive behavior (picking), in order to improve patients' quality of life in the long-term (25).

Finally, we believe that the assessment of ED patients is useful to tailor therapeutic options on the base of patients' needs. It is also recommended that, whenever possible, patients are assessed with more tools, in order to guarantee an integral assessment over all stages of illness $(13,18)$.

\section{AUTHORS CONTRIBUTION}

IB: Conceptualization, Methodology, Formal analysis, Writing-original draft. MJ: Conceptualization, Methodology, Formal analysis, Writing-original draft. NRD: Methodology, Writing-original draft. OG: Methodology, Writing-original draft. JAS: Methodology, Writing-original draft. MO: 
Methodology, Writing-original draft. PF: Methodology, Writing-original draft. DA: Methodology, Writingoriginal draft. RR: Methodology, Writing-original draft. RN: Methodology, Writing-original draft. JMCM: Writing-Review \& Editing, Validation. AV: WritingReview \& Editing, Validation. JVA: Methodology, Writing-original draft. JT: Conceptualization, Methodology, Formal analysis, Writing-original draft, Supervision.

\section{REFERENCES}

1. Lochner C, Roos A, Stein DJ. Excoriation (skin-picking) disorder: a systematic review of treatment options. Neuropsychiatr Dis Treat.2017;13:1867-72. https://dx.doi.org/10.2147/NDT.S121138

2. Martínez J, González C, Lermanda T. Fenomenología y diagnóstico diferencial de la dermatilomanía [Phenomenology and differential diagnosis of dermatilomania]. Rev Av.2007;8(1):126-42. URL.

3. Torales J, García O. Concepto y epidemiología del trastorno de excoriación [Concept and epidemiology of excoriation disorder]. In: Torales J, editor. El Trastor. Excoriación Excoriation Disord. 1st ed., Asunción: EFACIM; 2014, p. 4152.

4. Bohne A, Wilhelm S, Keuthen NJ, Baer L, Jenike MA. Skin Picking in German Students: Prevalence, Phenomenology, and Associated Characteristics. Behav Modif .2002;26 (3):320-39.

https://dx.doi.org/10.1177/0145445502026003002

5. Wong JW, Nguyen TV, Koo JY. Primary Psychiatric Conditions: Dermatitis Artefacta, Trichotillomania and Neurotic Excoriations. Indian J Dermatol.2013;58(1):44. https://dx.doi.org/10.4103/0019-5154.105287

6. American Psychiatric Association. Diagnostic and Statistical Manual of Mental Disorders. 5th ed. Arlington VA: Amer Psychiatric Pub Incorporated; 2013.

7. Lochner C, Simeon D, Niehaus DJH, Stein DJ. Trichotillomania and skin-picking: A phenomenological comparison. Depress Anxiety.2002;15(2):83-6. https://dx.doi.org/10.1002/da.10034

8. Keuthen NJ, Deckersbach T, Wilhelm S, Hale E, Fraim C, Baer L, et al. Repetitive Skin-Picking in a Student Population and Comparison With a Sample of Self-Injurious Skin-Pickers. Psychosomatics.2000;41

(3):210-5. https://dx.doi.org/10.1176/appi.psy.41.3.210

9. Keuthen N, Wilhelm S, Deckersbach T, Engelhard IM, Forker $A E$, Baer $L$, et al. The Skin Picking Scale. J Psychosom Res.2001;50(6):337-41. https://dx.doi.org/10.1016/S00223999(01)00215-X

10. Keuthen NJ, Deckersbach T, Wilhelm S, Engelhard I, Forker A, O'Sullivan RL, et al. The Skin Picking Impact Scale (SPIS): scale development and psychometric analyses. Psychosomatics.2001;42 (5):397-403. https://dx.doi.org/10.1176/appi.psy.42.5.397

11. Monzani B, Rijsdijk F, Cherkas L, Harris J, Keuthen N, Mataix-Cols D. Prevalence and heritability of skin picking in an adult community sample: a twin study. Am J Med Genet Part B Neuropsychiatr Genet Off Publ Int Soc Psychiatr Genet.2012;159B(5):605-10.

https://dx.doi.org/10.1002/ajmg.b.32067

12. Barrios I, Jafferany M, Ruiz Díaz N, Castaldelli-Maia JM, Ventriglio A, Torales J. Psychometric properties of the Spanish version of the Skin Picking Scale-Revised (SPS-R). J Obsessive-Compuls Relat Disord.2020;27:100586. https://dx.doi.org/10.1016/j.jocrd.2020.100586

13. Keuthen N, Siev J, Reese $\mathrm{H}$. Assessment of trichotillomania, pathological skin picking, and stereotypic movement disorder. In: Grant J, Stein D, Woods D, Keuthen $\mathrm{N}$, editors. Trichotillomania Skin Pick. Body-Focus. Repetitive Behav., Washington, D.C.: American Psychiatric Publishing; 2012, p. 129-50.

14. Snorrason I, Ólafsson RP, Flessner CA, Keuthen NJ, Franklin ME, Woods DW. The Skin Picking Scale-Revised: Factor structure and psychometric properties. J ObsessiveCompuls Relat Disord.2012;1(2):133-7. https://dx.doi.org/10.1016/j.jocrd.2012.03.001

15. Russell A, Pozo de Bolger A, Moses K, Luo A, Wootton BM. Psychometric properties of the excoriation (skin-picking disorder) dimensional scale. Clin Psychol.2020:cp.12207. https://dx.doi.org/10.1111/cp.12207

16. Gosling SD, Vazire S, Srivastava S, John OP. Should we trust web-based studies? A comparative analysis of six preconceptions about internet questionnaires. Am Psychol.2004;59(2):93-104. https://dx.doi.org/10.1037/0003-066X.59.2.93

17. Snorrason I, Olafsson RP, Flessner CA, Keuthen NJ, Franklin ME, Woods DW. The Skin Picking Impact Scale: Factor structure, validity and development of a short version. Scand J Psychol.2013;54(4):344-8. https://dx.doi.org/10.1111/sjop.12057

18. Barrios I, O’Higgins M, Espínola K, Gill MF, Ortiz M, Rodas $\mathrm{J}$, et al. The Spanish version of the Excoriation (Skin-Picking Disorder) Dimensional Scale (SPD-D): An assessment of its psychometric properties. J Obsessive-Compuls Relat Disord.2021;28:100611.

https://dx.doi.org/10.1016/i.jocrd.2020.100611

19. Herrero J. El Análisis Factorial Confirmatorio en el estudio de la Estructura y Estabilidad de los Instrumentos de Evaluación: Un ejemplo con el Cuestionario de Autoestima CA-14. Psychosoc Interv.2010;19(3):289-300. URL.

20. Taber KS. The Use of Cronbach's Alpha When Developing and Reporting Research Instruments in Science Education. Res Sci Educ.2018;48(6):1273-96. https://dx.doi.org/10.1007/s11165-016-9602-2

21. Stein DJ, Grant JE, Franklin ME, Keuthen N, Lochner C, Singer HS, et al. Trichotillomania (hair pulling disorder), skin picking disorder, and stereotypic movement disorder: toward DSM-V. Depress Anxiety.2010;27(6):611-26. https://dx.doi.org/10.1002/da.20700

22. Torales J, Rodríguez M, Riego V. Clínica del trastorno de excoriación [Excoriation disorder clinic]. El Trastor. Excoriación Excoriation Disord. 1st ed., Asunción: EFACIM; 2014, p. 53-9.

23. Torales J, Díaz NR, Barrios I, Navarro R, García O, O'Higgins $M$, et al. Psychodermatology of skin picking (excoriation disorder): A comprehensive review. Dermatol Ther.2020;33(4):e13661. https://dx.doi.org/10.1111/dth.13661

24. LeBeau RT, Mischel ER, Simpson HB, Mataix-Cols D, Phillips KA, Stein DJ, et al. Preliminary assessment of obsessive-compulsive spectrum disorder scales for DSM-5. J Obsessive-Compuls Relat Disord.2013;2(2):114-8. https://dx.doi.org/10.1016/j.jocrd.2013.01.005

25. Torales J, Ruiz Díaz N, González I. Trastorno de excoriación [The excoriation disorder]. In: Torales J, Malatesta $E$, editors. Psicodermatología Una Actual. Diagnóstica Ter. Las Entidades Clínicas Más Frecuentes Psychodermatology Diagn. Ther. Update Most Freq. Clin. Entities, Asunción: EFACIM; 2019, p. 80-106. 